\title{
Phaeoisaria vietnamensis sp. nov. and $P$. clematidis (hyphomycetes) from Vietnam
}

\section{Mel'nik VA ${ }^{1^{*}}$}

${ }^{1}$ Laboratory of the Systematics and Geography of Fungi, Komarov Botanical Institute, Russian Academy of Sciences, Professor Popov 2, St. Petersburg, 197376, Russia

Mel'nik VA 2012 - Phaeoisaria vietnamensis sp. nov. and P. clematidis (hyphomycetes) from Vietnam. Mycosphere 3(6), 957-960, Doi 10.5943 /mycosphere/3/6/10

A collection of a synnematous hyphomycete belonging in the genus Phaeoisaria was found on bark of a living unidentified liane in South Vietnam. It is described as a new species, Phaeoisaria vietnamensis, illustrated and compared with allied species. Furthermore, P. clematidis is recorded from two National Nature Parks in South Vietnam on different substrates.

Key words - anamorphic fungi - Ascomycota - new records - new taxon - Southeast Asia

\section{Article Information}

Received 13 November 2012

Accepted 14 November 2012

Published online 28 November 2012

*Corresponding author: V.A. Mel'nik - e-mail - vadim.melnik@ mail.ru

\section{Introduction}

In 2010 and 2011, mycologists of the Komarov Botanical Institute, Russian Academy of Sciences (St. Petersburg) and Moscow State University collected numerous samples of fungi and slime moulds in South Vietnam. Examinations of the samples have been carried out within the frame of a Research Program of the Russian-Vietnamese Tropical Research and Technological Center. Several anamorphic fungi have been found on substrates of these collections, including new species and new records for Vietnam. First results of examinations of the taxa concerned have already been published (Mel'nik 2011, 2012, Mel'nik et al. 2012). A synnematous hyphomycete belonging to the genus Phaeoisaria Höhn. was found in the samples concerned and proved to be a new species. Another rather common species of this genus, $P$. clematidis (Fuckel) S. Hughes, was encountered on different substrates among material from two National Nature Reserves in
South Vietnam.

\section{Methods}

Fresh samples collected during the course of field trips in Vietnam were dried at room temperature. The material was examined and photographed using a Zeiss microscope, Stemi 2000CS, and Axio Imager A1 equipped with Nomarski differential interference contrast optics. Identification was carried out through comparison with current taxonomic works of fungi under consideration. The examined specimens are deposited at DAOM and LE.

\section{Results}

The following description is based on fungal material recently found in Vietnam on branch litter of an unidentified deciduous liane.

Phaeoisaria vietnamensis Melnik, sp. nov. Figs 1-5 MycoBank 802275.

Etymology - vietnamensis, referring to 
Mycosphere Doi 10.5943/mycosphere/3/6/10

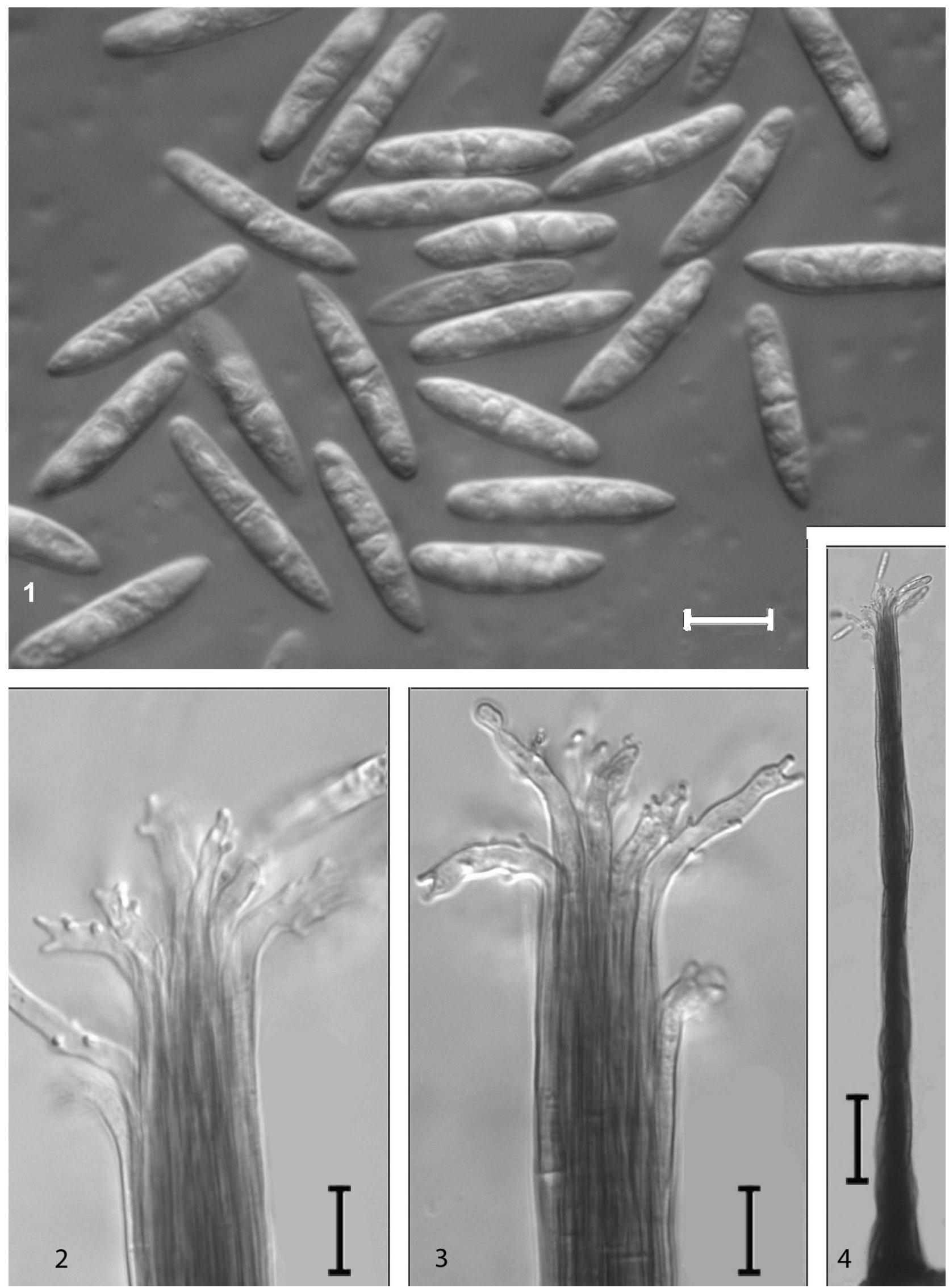

Figs. 1-4 - Phaeoisaria vietnamensis (ex holotype DAOM 242283): 1 conidia; 2-3 conidiogenous cells; 4 synnema. Bars: $1-3=10 \mu \mathrm{m} ; 4=50 \mu \mathrm{m}$. 


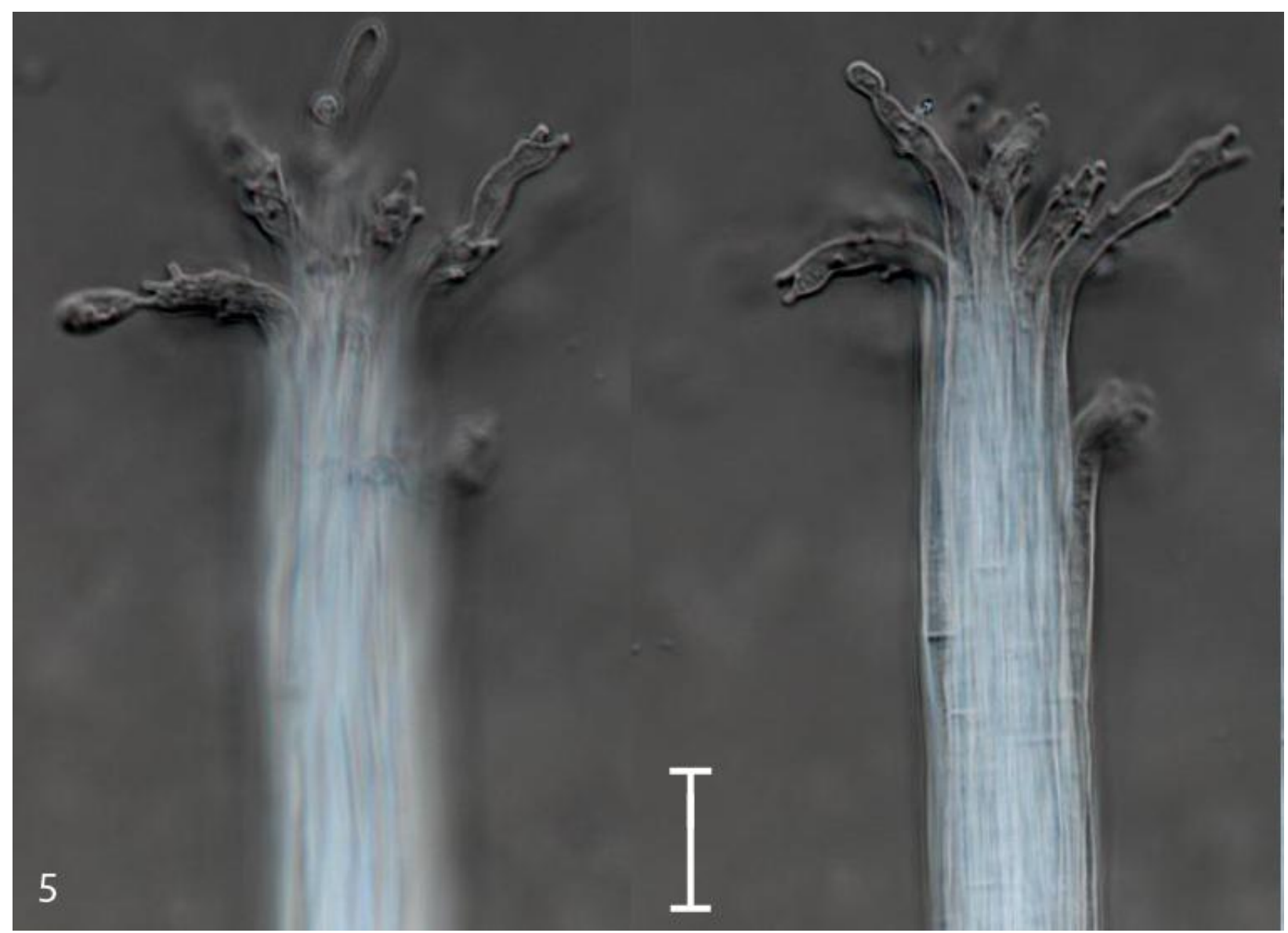

Fig. 5 - Phaeoisaria vietnamensis (ex holotype DAOM 242283): conidiogenous cells (micrograph taken in dark field to highlight the denticles). Bar: $=10 \mu \mathrm{m}$.

country where the fungus was found.

Phaeoisariae uniseptatae, P. sparsae, P. sparsae var. cubensis et $\mathrm{P}$. aguelerae similis, sed conidiis fusiformibus-subcylindraceis, obovoideis-subclavatis, apice obtuso, basi attenuate, rectis vel leniter curvatis, $18.5-23.5 \times 4.5-$ $5 \mu \mathrm{m}$.

Colonies effuse, brown. Conidiophores macronematous, in synnematous conidiomata, scattered, synnemata subulate or cylindrical, indeterminate, 330-380 $\mu \mathrm{m}$ high, 20-25(-30) $\mu \mathrm{m}$ wide at the base, $13-15 \mu \mathrm{m}$ beneath the fertile portion with conidiogenous cells, composed of medium to dark brown, smooth, septate parallel hyphae, 2-2.5(-3) $\mu \mathrm{m}$ wide, splaying out at the apex. Conidiogenous cells integrated, terminal and intercalary, polyblastic, sympodial, cylindrical or somewhat attenuated towards the tip, pale brown near base, subhyaline at the apex, $12-18 \times 2-2.5$ $\mu \mathrm{m}$, denticulate, denticles conspicuously cylindrical, $2-2.5 \times 1-1.5 \mu \mathrm{m}$. Conidia fusiformsubcylindrical to short obovoid-subclavate, 18.5-23.5 × 4.5-5 $\mu \mathrm{m}$, somewhat attenuated towards the base, apex obtuse, straight to slightly curved, with a single median septum, not constricted, hyaline, smooth, often guttulate. Teleomorph unknown.

Material examined - VIETNAM, Dong Nai Province, Cat Tien National Park, right bank of the river Dong Nai (upstream), dense tropical monsoon forest, near the plot "Ficus", on bark of living unidentified liane, 2 January 2011, Yu. Novozhilov (DAOM 242283, holotype; LE 263773, isotype).

\section{Discussion}

According to Seifert et al. (2011), Phaeoisaria Höhn. comprises 13 species. In the original publication, conidia of species of this genus were described as aseptate (see Ellis, 1971: 214). Later, de Hoog \& Papendorf (1976) mentioned that the conidia of Phaeoisaria are one- or rarely two-celled, while Seifert et al. (2011) only described ameroconidia, i.e. one-celled. However, some species assigned to Phaeoisaria deviate from the type species of this genus by having septate 
conidia. The inclusion of species with didymoto phragmosporous conidia is undoubtedly justified, does not constitute any reason to place the species concerned in another genus, but requires an emendation of the circumscription of Phaeoisaria to cover the whole range of conidia with different septations. Siboe et al. (1999) and Castañeda et al. (2002) keyed out all known species of Phaeoisaria including several taxa with 1-3septate conidia. A careful comparision of the material from Vietnam with other taxa having septate conidia showed that the fungus concerned is only comparable with $P$. uniseptata Mercado, P. sparsa B. Sutton, $P$. sparsa var. cubensis Mercado, Figueras \& Gené and, to a lesser extent, with $P$. aguilerae R.F. Castañeda, S. Velásquez \& Cano. However, the structure of the synnemata and the arrangement of conidiogenous cells and denticles in all of these species with 1-3septate conidia are distinct from the Vietnamese fungus, but the main distinguishing characters are to be found in the conidial shape, size and septation. In contrast to the species from Vietnam, which has fusiformsubcylindrical to short obovoid-subclavate conidia, attenuated towards the base, straight to slightly curved, $18.5-23.5 \times 4.5-5 \mu \mathrm{m}, P$. uniseptata has two-celled, fusiform, ellipsoid, cylindrical or clavate, but much smaller conidia, 3.6-10.2 × 1.6-3.4 $\mu \mathrm{m}, P$. sparsa differs in having fusiform to clavate, 0-3septate, smaller conidia, $10-15.5 \times 2.5-3.5 \mu \mathrm{m}$, and $P$. sparsa var. cubensis is characterized by having fusiform, cylindrical or clavate, sometimes slightly curved, $0-1(-4)$-septate, much smaller conidia, $(4-) 7-11(-17) \times(1.5-$ )2-3(-4) $\mu \mathrm{m}$. P. aguilerae, another comparable species, has clavate or cylindrical, curved conidia, 18-29.5 × 4-5 $\mu \mathrm{m}, 1(-3)$-septate, with obtuse, rounded apex, slightly uncinate, and truncate base. Based on these significant differences between enumerated species of Phaeoisaria and the new collection from Vietnam, the latter undoubtedly represents a different new species.

Phaeoisaria clematidis (Fuckel) S. Hughes, a relatively common and widespread species, was also found among the recently encountered collections from South Vietnam and is possibly a new record for the country. In
Lam Dong Province, Bi Dup - Nui Ba Nature Reserve, it was collected on wood of an unidentified tree (LE 262051), and in the Loc Bao District of this province, Loc Bao Forestry it was found on bark of unidentified tree (LE 263773). Other samples of this hyphomycete are from Dong Nai Province, Vinh Cuu Nature Reserve, on bark of a living tree belonging to Baringtonia sp. (LE 263712), on branch litter of Pinus kesiya (LE 263714), and on bark of an unidentified liane (LE 263715).

\section{Acknowledgements}

Yury Novozhilov, St. Petersburg, Russia is thanked for providing fungal collections from South Vietnam and Uwe Braun, Halle (Saale), Germany for valuable comments and corrections to the manuscript. I am also much obliged to Keith Seifert, Ottawa, Canada, for his useful comments.

\section{References}

Castañeda Ruiz RF, Velásquez S, Cano J, Saikawa M, Guarro J. 2002 Phaeoisaria aguilerae anam. sp. nov. from submerged wood in Cuba with notes and reflections in the genus Phaeoisaria. Cryptogamie, Mycologie, 23, 9-18.

Ellis MB. 1971 - Dematiaceous Hyphomycetes. CMI, Kew.

Hoog GS de, Papendorf MC. 1976 - The genus Phaeoisaria. Persoonia 8, 407-414.

Mel'nik VA. 2011 - Anamorphic fungi of Vietnam. I. Mikologiya i Fitopatologiya 45, 323-331 [in Russian].

Mel'nik VA. 2012 - A new species of Ardhachandra (hyphomycetes) from Vietnam. Mycosphere 3,922-924.

Mel'nik VA, Novozhilov YuK, Popov ES, Alexandrova AV. 2012 - Anamorphic fungi of Vietnam. II. Mikologiya i Fitopatologiya 46, 323-331 [in Russian].

Seifert K, Morgan-Jones G, Gams W, Kendrick B. 2011 - The Genera of Hyphomycetes. CBS Biodiversity Series 9, 1-997.

Siboe GM, Kirk PM, Cannon PF. 1999 - New dematiaceous hyphomycetes from Kenyan rare plants. Mycotaxon 73, 283 302. 